\title{
Flavonoids and a Naphthopyranone from Eriocaulon ligulatum and Their Mutagenic Activity
}

\author{
Marcelo Aparecido da Silva, ${ }^{a}$ Ana Paula Siqueira Oliveira, ${ }^{b}$ Miriam SAnnomiya, ${ }^{a}$ \\ Paulo Takeo SAno, ${ }^{c}$ Eliana Aparecida VARAnda, ${ }^{b}$ Wagner VILEgas, ${ }^{a}$ and \\ Lourdes Campaner dos SANTOS*,a \\ ${ }^{a}$ Department of Organic Chemistry, Instituto de Química de Araraquara, São Paulo State University (UNESP); C.P. 355, \\ Araraquara, São Paulo 14801-970, Brazil: ${ }^{b}$ Department of Biology, Faculdade de Ciências Farmacêuticas de Araraquara, \\ São Paulo State University (UNESP); C.P. 502, Araraquara, São Paulo 14801-902, Brazil: and ${ }^{c}$ Department of Botany, \\ Instituto de Biociências, São Paulo University; C.P. 11461, São Paulo 054220-970, Brazil.
}

Received May 15, 2007; accepted August 10, 2007

A new acylated flavonoid, 6,4'-dimethoxyquercetin-3- $O-\beta$-D-6" $[3,4,5$-trihydroxy (E)-cinnamoyl $]$ glucopyranoside, and a naphthopyranone dimer, named eriocauline, together with 2 other known flavonoids, 6methoxyapigenin-7- $O$ - $\beta$-D-glucopyranoside and 6-methoxyapigenin-7- $O$ - $\beta$-D-allopyranoside, have been isolated from the capitulae of Eriocaulon ligulatum. The compounds were identified using spectroscopic methods (HRESI-MS, and 1-D and 2-D NMR). The methanol extract exhibited mutagenic activity in the Salmonella/microsome assay, in strains TA100, TA97a and TA102 and for dichloromethane extract tested in strain TA98.

Key words Eriocaulon ligulatum; Eriocaulaceae; naphthopyranone; flavonoid; Ames test; high speed counter-current chromatography

Eriocaulon ligulatum (VelL.) L. B. Sмiтh. (the pipewort family, Eriocaulaceae), called "botão-dourado" (golden bud), is exported to Europe, Japan and North America as an ornamental flower, representing an important source of income to the population of Minas Gerais State, Brazil. Scientific research on Eriocaulon is scarce and very little is known about its chemical constituents. The flavonols quercetagetin (8-hydroxyquercetin) and patuletin (6-methoxyquercetin) were identified in the leaves of E. septangulare (common pipewort), E. brownianum, E. nilagirense, E. decangulare, E. sexangulare, E. wightianum. ${ }^{1)}$ Four flavonoids, including (2S)-3', $4^{\prime}$-methylenedioxy-5,7-dimethoxyflavan and hispidulin [7-(6-E- $p$-coumaroyl- $\beta$-D-glucopyranoside)], as well as tocopherol, have been identified in the capitulae of E. buergerianum KoERn. ${ }^{2}$ Other derived flavones and glycosylated naphthopyranones were isolated from the capitulae of Eriocaulon. ${ }^{3)}$

Taxonomic studies to delimit the genus, about which there is still some confusion, and the biological investigation into the isolated molecules of Eriocaulaceae are of great importance because several molecules possess antioxidant, ${ }^{4}{ }^{4}$ cytotoxic, mutagenic, ${ }^{5,6)}$ and antiulcerogenic activity. ${ }^{7,8)}$

We report here the isolation of taxonomically relevant flavonoids and a naphthopyranone dimer isolated from methanol and dichloromethane extracts from capitulae of $E$. ligulatum, respectively, and also the mutagenic activity of methanol and dichloromethane extracts assayed using the Ames test.

\section{Results and Discussion}

Chromatographic fractionation of the extracts of E. ligulatum afforded the substances presented in Figs. 1-3. When revealed with Natural Product/Polyethylenoglycol Reagent (NP/PEG Reagent), compounds $\mathbf{1}-\mathbf{3}$ showed yellow spots, characteristic of flavonoids. ${ }^{9)}$ Compounds $\mathbf{1}-\mathbf{4}$ were determined to be 6-methoxyapigenin-7- $O-\beta$-D-glucopyranoside (1), 6-methoxyapigenin-7- $O$ - $\beta$-D-allopyranoside (2), 6,4' dimethoxyquercetin-3- $O-\beta$-D-6" [3,4,5-trihydroxy $(E)$-cin- namoyl]glucopyranoside (3) and eriocauline (4). Compounds 3 and $\mathbf{4}$ were identified using spectroscopic methods (IR, UV, HR-ESI-MS and NMR 1-D and 2-D).

Compound 3 was obtained as a pale yellow amorphous solid. The IR spectrum presented bands at $3387 \mathrm{~cm}^{-1}\left(v_{\mathrm{O}-\mathrm{H}}\right)$, $1637 \mathrm{~cm}^{-1}\left(v_{\mathrm{C}=\mathrm{O}}\right)$ and $1604 \mathrm{~cm}^{-1}\left(v_{\mathrm{C}=\mathrm{C}}\right)$. The UV spectra showed absorption bands at 240 and $336 \mathrm{~nm}$. The positive HR-ESI-MS mass spectrum gave the pseudomolecular ion $[\mathrm{M}+\mathrm{H}]^{+}$at $\mathrm{m} / z 687.1561$ corresponding to the molecular formula $\mathrm{C}_{32} \mathrm{H}_{30} \mathrm{O}_{17}$. The adduct with sodium $[\mathrm{M}+\mathrm{Na}]^{+}$appeared at $\mathrm{m} / \mathrm{z} 693.1434$ and the adduct with potassium $[\mathrm{M}+\mathrm{K}]^{+}$appeared at $\mathrm{m} / z$ 725.2463. The ${ }^{13} \mathrm{C}$-NMR and DEPT spectra of 3 showed 32 signals, 6 of which could be assigned to a glucopyranosyl moiety (Table 1). Sixteen other signals were similar to those of 6-methoxyquercetin. ${ }^{10)}$ The remaining 7 signals are compatible with a 3,4,5-trihydroxycinnamoyl moiety. ${ }^{10)}$ The ${ }^{1} \mathrm{H}-\mathrm{NMR}$ of $\mathbf{3}$ clearly indicated a

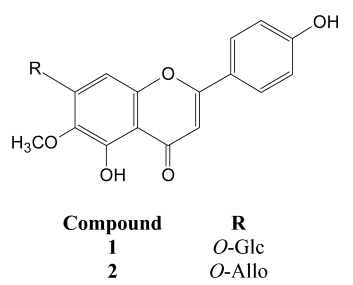

Fig. 1. Compounds Isolated from E. ligulatum

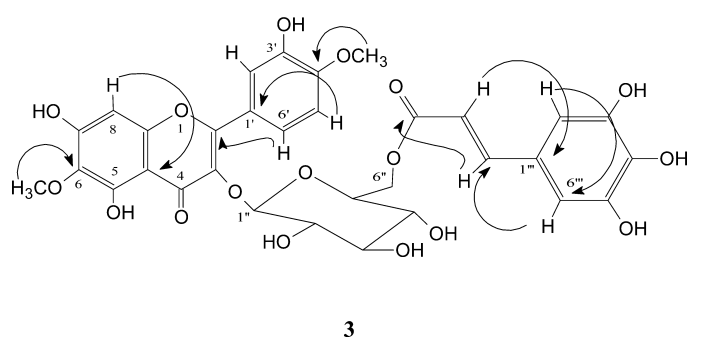

Fig. 2. Acyl Flavonoid 3 from E. ligulatum, Showing Relevant $(-)$ HMBC Interactions 


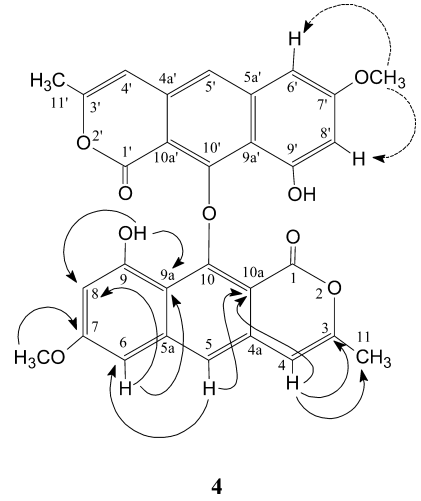

Fig. 3. Eriocauline 4 from E. ligulatum, Showing Relevant ( $\longrightarrow$ ) HMBC and (----) Long-Range NOESY Interactions

Table 1. NMR Spectral Data for Compound 3 (DMSO- $d_{6}, 500,125 \mathrm{MHz}$, $J$ in $\mathrm{Hz}$ )

\begin{tabular}{|c|c|c|c|}
\hline Position & ${ }^{1} \mathrm{H}$ & ${ }^{13} \mathrm{C}$ & HMBC \\
\hline 2 & & 156.5 & $C-6^{\prime}$ \\
\hline 3 & & 132.6 & \\
\hline 4 & & 177.7 & \\
\hline 5 & & 151.4 & \\
\hline 6 & & 131.3 & \\
\hline 7 & & 157.4 & \\
\hline 8 & $6.49(\mathrm{~s})$ & 97.4 & C-6; C-10 \\
\hline 9 & & 152.2 & \\
\hline 10 & & 104.3 & \\
\hline $1^{\prime}$ & & 120.9 & \\
\hline $2^{\prime}$ & $7.55(\mathrm{~d}, J=2.5)$ & 116.0 & \\
\hline $3^{\prime}$ & & 144.7 & \\
\hline $4^{\prime}$ & & 148.1 & \\
\hline $5^{\prime}$ & $6.85(\mathrm{~d}, J=8.0)$ & 115.2 & $\mathrm{C}-1^{\prime} ; \mathrm{C}-3^{\prime}$ \\
\hline $6^{\prime}$ & $7.53(\mathrm{dd}, J=8.0,2.5)$ & 121.5 & $\mathrm{C}-2 ; \mathrm{C}-2^{\prime}$ \\
\hline $6-\mathrm{OCH}_{3}$ & $3.70(\mathrm{~s})$ & 59.9 & $\mathrm{C}-6$ \\
\hline $4^{\prime}-\mathrm{OCH}_{3}$ & $3.88(\mathrm{~s})$ & 56.1 & $\mathrm{C}-4^{\prime}$ \\
\hline $5-\mathrm{OH}$ & $12.71(\mathrm{~s})$ & & \\
\hline \multicolumn{4}{|l|}{ Glucose } \\
\hline $1^{\prime \prime}$ & $5.51(\mathrm{~d}, J=7.5)$ & 100.5 & \\
\hline $2^{\prime \prime}$ & 3.24 & 73.7 & \\
\hline $3^{\prime \prime}$ & 2.64 & 76.3 & \\
\hline $4^{\prime \prime}$ & 3.19 & 69.6 & \\
\hline $5^{\prime \prime}$ & 2.78 & 74.2 & \\
\hline $6^{\prime \prime}$ & $4.14_{\mathrm{a}} \mathrm{e} 3.72_{\mathrm{b}}$ & 67.4 & \\
\hline \multicolumn{4}{|l|}{ Cinnamyl } \\
\hline $1^{\prime \prime \prime}$ & & 124.5 & $\mathrm{C}-4^{\prime \prime \prime}$ \\
\hline $2^{\prime \prime \prime}$ & $7.08(\mathrm{~d}, J=2.5)$ & 105.9 & C- $\beta$ \\
\hline $3^{\prime \prime \prime}$ & & 148.5 & \\
\hline $4^{\prime \prime \prime}$ & & 138.1 & \\
\hline $5^{\prime \prime \prime}$ & & 148.1 & \\
\hline $6^{\prime \prime \prime}$ & $7.08(\mathrm{~d}, J=2.5)$ & 105.9 & C-4"'; C-2 $2^{\prime \prime \prime} ; \mathrm{C}-\beta$ \\
\hline$\alpha$ & $6.33(\mathrm{~d}, J=16.0)$ & 115.0 & $C-1^{\prime \prime \prime}$ \\
\hline$\beta$ & $7.49(\mathrm{~d}, J=16.0)$ & 145.1 & $\mathrm{C}-2^{\prime \prime \prime} ; \mathrm{C}=\mathrm{O}$ \\
\hline $\mathrm{C}=\mathrm{O}$ & & 165.5 & \\
\hline
\end{tabular}

singlet for an OH-group at $\delta 12.71$, due to hydrogen bonding to the C-4 carbonyl. A doublet at $\delta 7.55(1 \mathrm{H}, J=2.5 \mathrm{~Hz})$, a double doublet at $\delta 7.53(1 \mathrm{H}, J=8.0,2.5 \mathrm{~Hz})$ and a doublet at $\delta 6.85(1 \mathrm{H}, J=8.0 \mathrm{~Hz})$ are related to the $\mathrm{H}-2^{\prime}, \mathrm{H}-5^{\prime}$ and $\mathrm{H}-$ $6^{\prime}$, respectively, of the B-ring of the aglycone moiety. The singlet at $\delta 6.49$ was assigned to $\mathrm{H}-8$. The signal at $\delta 7.08$ $(2 \mathrm{H}, J=2.5 \mathrm{~Hz})$ was attributed to $\mathrm{H}-2^{\prime \prime \prime} / \mathrm{H}-6^{\prime \prime \prime}$ of a 3,4,5-trihydroxy-cinnamoyl moiety, respectively. The two doublets $(1 \mathrm{H}$ each, $J=16.0 \mathrm{~Hz}$ ) at $\delta 6.33$ and $\delta 7.49$ were assigned to $\mathrm{H}-\alpha$ and $\mathrm{H}-\beta$ of the 3,4,5-trihydroxy-cinnamoyl moiety with $E$
Table 2. NMR Spectral Data for Compound 4 (DMSO- $d_{6}, 500,125 \mathrm{MHz}$, $J$ in $\mathrm{Hz}$ )

\begin{tabular}{crrrl}
\hline \hline Position & \multicolumn{1}{c}{${ }^{1} \mathrm{H}$} & ${ }^{13} \mathrm{C}$ & NOESY & \multicolumn{1}{c}{ HMBC } \\
\hline 1 & & 174.4 & \\
3 & & 151.0 & \\
4 & $6.30(\mathrm{~s})$ & 105.3 & $\mathrm{C}-5 ; \mathrm{C}-10 \mathrm{a} ; \mathrm{C}-11$ \\
$4 \mathrm{a}$ & & 133.8 & \\
5 & $6.54(\mathrm{~s})$ & 105.9 & $\mathrm{C}-4 ; \mathrm{C}-6$; C-9a; C-10a \\
$5 \mathrm{a}$ & & 141.3 & \\
6 & $6.48(\mathrm{~d}, J=2.0)$ & 97.2 & $\mathrm{C}-8 ; \mathrm{C}-9 \mathrm{a}$ \\
7 & & 166.2 & \\
8 & $6.08(\mathrm{~d}, J=2.0)$ & 97.3 & $\mathrm{C}-6$ \\
9 & & 162.6 & \\
$9 \mathrm{a}$ & & 111.2 & \\
10 & & 162.2 & \\
$10 \mathrm{a}$ & & 97.4 & & \\
$11-\mathrm{CH}_{3}$ & $2.13(\mathrm{~s})$ & 18.5 & & \\
$7-\mathrm{OCH}_{3}$ & $3.79(\mathrm{~s})$ & 54.9 & $\mathrm{H}-6 ; \mathrm{H}-8$ & $\mathrm{C}-7$ \\
$9-\mathrm{OH}^{14.2(\mathrm{~s})}$ & & & $\mathrm{C}-9 \mathrm{a} ; \mathrm{C}-8$ \\
\hline
\end{tabular}

stereochemistry, respectively. The TOCSY-1D experiment with irradiation at $\delta 5.51(1 \mathrm{H}, \mathrm{d}, J=7.5 \mathrm{~Hz})$ evidenced the spin system of a D-glucose having a $\beta$-configuration. The two singlets at $\delta 3.70(3 \mathrm{H})$ and $\delta 3.88(3 \mathrm{H})$ indicated the presence of the two $\mathrm{OCH}_{3}$ groups. The assignment of each signal was based on HMQC and HMBC experiments (Fig. 2, Table 1). The NOESY experiment irradiated at $\delta 6.85\left(\mathrm{H}-5^{\prime}\right)$ indicated that the $\mathrm{OCH}_{3}$ group at $\delta 3.88$ is linked to the C-4' position. The HMBC experiment showed correlations between the proton at $\delta 3.70\left(\mathrm{OCH}_{3}\right)$ with the carbon signal at $\delta$ 131.3 (C-6), between the hydrogen signal at $\delta 3.88\left(\mathrm{OCH}_{3}\right)$ and the carbon signal at $\delta 148.1\left(\mathrm{C}-4^{\prime}\right)$, between the hydrogen signal at $\delta 5.51\left(\mathrm{H} 1^{\prime \prime}\right)$ with the carbon signal at $\delta 132.6$ $(\mathrm{C}-3)$, and between the hydrogen signal at $\delta 4.14\left(\mathrm{H6}^{\prime \prime}\right)$ and the carbonyl signal at $\delta 165.5$. This value refers to the carbonyl of the 3,4,5-trihydroxy-cinnamic acid.

In the HR-ESI-MS spectrum of $\mathbf{3}$, the signal corresponding to the loss of the cinnamoyl derivative moiety [M$\left.\mathrm{C}_{9} \mathrm{H}_{8} \mathrm{O}_{4}+\mathrm{H}\right]^{+}$was clearly observed at $m / z$ 507.1139. Further loss of the glucose unit produced the fragment [M$\left.\mathrm{C}_{16} \mathrm{H}_{20} \mathrm{O}_{11}+\mathrm{H}\right]^{+}$at $m / z$ 301.1436, which corresponds to the protonated aglycone. Thus 3 was characterized as $6,4^{\prime}$ dimethoxyquercetin-3- $O$ - $\beta$-D-6"[3,4,5-trihydroxy $\quad(E)$-cinnamoyl]glucopyranoside.

Compound $\mathbf{4}$ was obtained as a yellow amorphous solid. The IR spectra showed absorptions at $3416 \mathrm{~cm}^{-1}\left(v_{\mathrm{O}-\mathrm{H}}\right)$ and $1638 \mathrm{~cm}^{-1}\left(v_{\mathrm{C}=\mathrm{O}}\right)$. The HR-ESI-MS in the positive mode displayed a pseudomolecular ion $[\mathrm{M}+\mathrm{H}]^{+}$at $m / z 527.1342$, corresponding to the molecular formula $\mathrm{C}_{30} \mathrm{H}_{22} \mathrm{O}_{9}$, and the potassium adduct $[\mathrm{M}+\mathrm{K}]^{+}$at $m / z 565.2244$. The structure of 4 was elucidated also using 1-D and 2-D NMR experiments (Table 2). The ${ }^{1} \mathrm{H}-\mathrm{NMR}$ spectrum of $\mathbf{4}$ displayed signals of aromatic protons at $\delta 6.48(2 \mathrm{H}, \mathrm{d}, J=2.0 \mathrm{~Hz})$ and $\delta 6.08(2 \mathrm{H}$, d, $J=2.0 \mathrm{~Hz}), \delta 6.54(2 \mathrm{H}, \mathrm{s})$. Also evident were singlets at $\delta$ $3.79(6 \mathrm{H})$, typical of aromatic methoxyl groups. The ${ }^{13} \mathrm{C}-$ NMR and DEPT spectra of $\mathbf{4}$ presented 15 signals and their chemical shifts correlated well with those of paepalantine. ${ }^{11)}$ The main differences occurred in the chemical shifts of ring $\mathrm{C}$, while the chemical shifts of rings $\mathrm{A}$ and $\mathrm{B}$ remained almost unchanged. Assignments of the ${ }^{1} \mathrm{H}$ - and ${ }^{13} \mathrm{C}$-NMR data of 4 were based on HMBC, HMQC, and NOESY experiments (Table 2). All these data provided evidence of a 
Table 3. Mutagenic Activity Expressed as the Mean and Standard Deviation of the Number of Revertants/Plate in Bacterial Strains TA98, TA100, TA97a and TA102 Exposed to Extracts of E. ligulatum, at Various Doses, with (+S9) or without $(-\mathrm{S} 9)$ Metabolic Activation

\begin{tabular}{|c|c|c|c|c|c|c|c|c|}
\hline \multirow{3}{*}{$\begin{array}{l}\text { Treatment } \\
\text { mg/plate }\end{array}$} & \multicolumn{8}{|c|}{ Revertants/plate in Salmonella typhimurium strains } \\
\hline & \multicolumn{2}{|c|}{ TA 100} & \multicolumn{2}{|c|}{ TA 98} & \multicolumn{2}{|c|}{ TA $97 \mathrm{a}$} & \multicolumn{2}{|c|}{ TA 102} \\
\hline & $-\mathrm{S} 9^{c)}$ & $+\mathrm{S}^{b)}$ & $-\mathrm{S}^{a)}$ & $+\mathrm{S} 9^{b)}$ & $-\mathrm{S} 9^{a)}$ & $+\mathrm{S} 9^{b)}$ & $-\mathrm{S} 9^{d)}$ & $+\mathrm{S} 9^{b)}$ \\
\hline 0 & $121 \pm 5$ & $92 \pm 8$ & $19 \pm 5$ & $24+4$ & $133 \pm 19$ & $159+10$ & $293 \pm 17$ & $335+20$ \\
\hline 0.6 & $189 \pm 7(1.3)$ & $154+18(1.7)^{*}$ & $29 \pm 1(1.5)$ & $34+7(1.4)$ & $1052 \pm 97(7.9)^{* *}$ & $836+124(5.2)^{* *}$ & $328 \pm 14(1.1)$ & $746+86(2.2)^{* *}$ \\
\hline 1.2 & $234 \pm 15(1.5)$ & $157+20(1.7)^{*}$ & $31 \pm 0(1.6)$ & $28+5(1.2)$ & $1209 \pm 142(9.0)^{* *}$ & $844+18(5.3)^{* *}$ & $295 \pm 18(1.0)$ & $681+71(2.0)^{* *}$ \\
\hline 2.3 & $231 \pm 16(1.5)$ & $195+51(2.1)^{*}$ & $26 \pm 4(1.4)$ & $34+3(1.4)$ & $1113 \pm 103(8.4)^{* *}$ & $747+78(4.7)^{* *}$ & $311 \pm 8(1.1)$ & $1093+270(3.3)^{*}$ \\
\hline 4.6 & $135 \pm 15(1.1)$ & $171+23(1.9)^{*}$ & $34 \pm 4(1.8)$ & $31+2(1.3)$ & $952 \pm 65(7.2)^{* *}$ & $541+50(3.4)^{* *}$ & $287 \pm 18(1.0)$ & $568+86(1.7)^{*}$ \\
\hline 6.9 & $148 \pm 3(1.2)$ & $116+17(1.3)$ & $32 \pm 10(1.7)$ & $30+5(1.3)$ & $619 \pm 56(4.7)^{* *}$ & $759+127(4.8)^{* *}$ & $296+16(1.0)$ & $730+184(2.2)$ \\
\hline DCM & $-\mathrm{S} 9$ & $+\mathrm{S} 9$ & $-\mathrm{S} 9$ & $+\mathrm{S} 9$ & $-\mathrm{S} 9$ & $+\mathrm{S} 9$ & $-\mathrm{S} 9$ & $+\mathrm{S} 9$ \\
\hline 0 & $173 \pm 29$ & $92+8$ & $19 \pm 5$ & $24+4$ & $159 \pm 24$ & $159+10$ & $252 \pm 12$ & $335+20$ \\
\hline 0.7 & $177 \pm 12(1.0)$ & $111+9(1.2)$ & $28 \pm 2(1.5)$ & $29+3(1.2)$ & $162 \pm 9(1.0)$ & $190+22(1.2)$ & $231 \pm 15(0.9)$ & $395+45(1.2)$ \\
\hline 1.4 & $178 \pm 13(1.0)$ & $111+14(1.2)$ & $26 \pm 6(1.4)$ & $24+7(1.0)$ & $135 \pm 30(0.9)$ & $186+32(1.2)$ & $221 \pm 25(0.9)$ & $395+9(1.2)$ \\
\hline 2.9 & $190 \pm 12(1.1)$ & $145+21(1.6)$ & $32 \pm 4(1.7)$ & $19+3(0.8)$ & $147 \pm 9(0.9)$ & $143+3(0.9)$ & $211 \pm 12(0.8)$ & $343+14(1.0)$ \\
\hline 5.8 & $179 \pm 21(1.0)$ & $114+8(1.2)$ & $46 \pm 6(2.4)^{*}$ & $22+6(0.9)$ & $153 \pm 12(1.0)$ & $166+27(1.0)$ & $246 \pm 10(1.0)$ & $365+5(1.1)$ \\
\hline 8.7 & $120 \pm 15(0.7)$ & $120+20(1.3)$ & $46 \pm 14(2.4)^{*}$ & $17+2(0.7)$ & $156 \pm 13(1.0)$ & $143+13(0.9)$ & $272 \pm 16(1.1)$ & $333+13(1.0)$ \\
\hline Control+ & $955 \pm 92$ & $2174+348$ & $726 \pm 99$ & $480+43$ & $975 \pm 46$ & $2189+171$ & $1650 \pm 25$ & $3364+437$ \\
\hline
\end{tabular}

MeOH: methanol extract; DCM: dichloromethane extract; $0=$ negative control (DMSO, $100 \mu \mathrm{l} /$ plate). Control +: Positive control: $a$ ) NPD (4-nitro- $O$-phenylenediamine, $10.0 \mu \mathrm{g} / \mathrm{plate}) ; b) 2$-anthramine $(1.25 \mu \mathrm{g} / \mathrm{plate}) ; c)$ sodium azide $(1.25 \mu \mathrm{g} / \mathrm{plate}) ; d)$ mitomycin $(0.5 \mu \mathrm{g} / \mathrm{plate}) . * p<0.05$ (ANOVA), $* * p<0.01(\mathrm{ANOVA})$. The values in parenthesis $=$ mutagenic index.

dimeric structure for compound 4.

In the HMBC spectrum (Fig. 3, Table 2) diagnostic longrange correlations were observed between the proton signal at $\delta 6.08(\mathrm{H}-8)$ and the carbon resonances at $\delta 97.2(\mathrm{C}-6)$, $111.2(\mathrm{C}-9 \mathrm{a}), 162.6(\mathrm{C}-9)$, and $166.2(\mathrm{C}-7)$; the proton signal at $\delta 6.48(\mathrm{H}-6)$ and the carbon resonances at $\delta 97.4(\mathrm{C}-8)$, $111.2(\mathrm{C}-9 \mathrm{a}), 105.9(\mathrm{C}-5)$ and $166.2(\mathrm{C}-7)$; the proton signal at $\delta 6.54(\mathrm{H}-5)$ and the carbon resonances at $\delta 97.2(\mathrm{C}-6)$, $111.2(\mathrm{C}-9 \mathrm{a}), 97.4(\mathrm{C}-10 \mathrm{a})$ and $141.3(\mathrm{C}-5 \mathrm{a})$; the proton signals at $\delta 6.30(\mathrm{H}-4)$ and the carbon resonances at $\delta 151.0(\mathrm{C}$ 3), 133.8 (C-4a) and 97.4 (C-10a), and the methyl singlet at $\delta$ $2.13\left(\mathrm{CH}_{3}-11\right)$ and the carbon signal at $\delta 151.0(\mathrm{C}-3)$. A further correlation was observed between the proton signal at $\delta 3.79\left(\mathrm{OCH}_{3}\right)$ and the carbon signal at $\delta 166.2(\mathrm{C}-7)$. On the basis of the above evidence, it was possible to deduce the presence of 5-desmethoxypaepalantine as one of the monomeric units of the molecule. The HMBC spectrum also shows a correlation between the signal at $\delta 14.2(\mathrm{OH}-9)$ with the carbon signal at $\delta 97.4(\mathrm{C}-8), \delta 162.6(\mathrm{C}-9)$ and $\delta 111.2$ (C-9a). These correlations and the absence of the signal at $\delta$ $13.2(\mathrm{OH}-10)$ suggested the occurrence of a free hydroxyl at position 9 and $9^{\prime} .{ }^{12)}$ On the basis of these findings, the linkage between two monomeric units was deduced to be between $\mathrm{C} 10 / \mathrm{C}_{10} 0^{\prime}$ and the structure of the eriocauline 4 was established. The $\mathrm{CD}$ and $[\alpha]_{\mathrm{D}}$ indicate that compound 4 has atropoisomerism.

Dimeric naphthopyranones were previously isolated from plants pertaining to this family. Planifoline, a dimer with an ethereal bond between two $\mathrm{OH}$ groups at position 9, was isolated from Paepalanthus planifolius, ${ }^{12)}$ whereas a dimer linked through a $\mathrm{C}-\mathrm{C}$ bond was isolated from $P$. bromelioides. ${ }^{13)}$

Chemical constituents have previously proved to be an important taxonomic character in Eriocaulaceae. Naphthopyranones and flavonols are the major compounds of many Paepalanthus species. ${ }^{14,15)}$ These classes of secondary metabolites are absent in species belonging to both the Syng- onanthus and the Leiothrix genus. Leiothrix produces mainly flavones and xanthones, ${ }^{16,17)}$ while Syngonanthus afforded only flavones. ${ }^{18-20)}$ From the evolutionary point of view, it is considered that Leiothrix and Syngonanthus may have originated from Paepalanthus, in a more advanced position than Eriocaulon, ${ }^{21}$ since the substitution of flavonols with flavones, ${ }^{3)}$ is a well established condition. ${ }^{22}$ )

Naphthopyranones are a relatively rare class of natural compounds and the presence of this class of compounds in E. ligulatum suggests an approximation between Eriocaulon and Paepalanthus, whereas the presence of the flavones align Eriocaulon in a less advanced sister group relative to the Leiothrix/Syngonanthus clade. Our results reinforce the cladistic analysis method based on morphological and cytological characteristics reported by Giulietti et al. ${ }^{23)}$

Short-term tests that detect genetic damage can afford the information needed to evaluate the carcinogenic risks of chemicals to humans. The Ames test, recommended for testing the mutagenicity of chemical compounds with potential pharmacological application, was used in the present study. ${ }^{24,25)}$

The mutagenic activity data obtained in the Salmonella/ microsome assays are shown in Table 3 , in which it can be seen that the methanol extract was mutagenic to the TA100 $(+$ S9), TA97a $(-$ S9, +S9) and TA102 $(+$ S9) strains. With respect to the strains, we can conclude that mutations of the frame-shift type were mainly induced and were detected by TA97a with a mutagenic index (MI) of up to 9.0, besides mutations induced by substitutions of base pairs, which were detected in the strains TA100 and TA102. In these strains, the largest MIs obtained were 2.1 and 3.3 respectively.

Two naphthopyranones, paepalantine- $9-O-\beta$-D-glucopyranoside and paepalantine-9- $O-\beta$-D-allopyranosyl were identified in the methanol extract of the capitulae and escape of E. ligulatum. ${ }^{3)}$ Previously, Varanda et al. ${ }^{26)}$ observed that paepalantine-9- $O$ - $\beta$-D-glucopyranoside isolated from Paepalanthus bromelioides was mutagenic in TA97a. There- 
fore, this naphthopyranone might have contributed to the mutagenic effect observed in the methanol extract of E. ligulatum.

In addition to this, in the methanol extract, there was a prevalence of flavonoids. Flavonoids are known for their beneficial activities with respect to the human health, ${ }^{27,28)}$ but several studies have demonstrated that these compounds possess genotoxic activity. ${ }^{29-31)}$

The dichloromethane extract only presented mutagenic activity in TA98 $(-\mathrm{S} 9)$ with a maximum MI value of 2.4. In this extract, there is a prevalence of the naphthopyranone. Therefore the increase in revertants provoked by the dichloromethane extract could be due to the presence of eriocauline. Experiments will be carried out to confirm the mutagenic activity of that substance.

\section{Experimental}

General Experimental Procedure Structural identification of the compounds using NMR spectra in DMSO- $d_{6}$ (compounds 1-4) were obtained using a Varian INOVA 500 operating at $500 \mathrm{MHz}$ for ${ }^{1} \mathrm{H}-\mathrm{NMR}$ and $125 \mathrm{MHz}$ for ${ }^{13} \mathrm{C}$-NMR using 1-D and 2-D experiments (inverse detection ${ }^{1} \mathrm{H}-{ }^{13} \mathrm{C}$ HSQC and HMBC). For compounds $\mathbf{1}-\mathbf{4}$, samples were dissolved in methanol and injected directly into the mass spectrometer through a Rheodyne injector. Acetonitrile was used as the solvent and nitrogen gas was used as the drying gas and for the nebulization. HR-ESI-MS of $\mathbf{3}-\mathbf{4}$ was performed using an ultrOTOF-Q ESI-TOF Mass Spectrometer Bruker Daltonics (Billerica, MA, U.S.A.) instrument. The melting point was measured on a digital MQ APF-301 (Microquímica, Brazil) apparatus. UV spectra were recorded on a HACH UV-Vis DR/4000 spectrophotometer. IR spectra were obtained using a Shimadzu FT-IR 8300 spectrophotometer. Optical rotation: Jasco-P-1020 polarimeter $\left(27^{\circ} \mathrm{C}\right)$. Circular dichroism spectra were recorded on a JASCO CD-2095 Plus Chiral Detector.

TLC was performed on $200 \mu \mathrm{m}$ silica gel (Sorbent Technologies) and visualized using UV light $(254,365 \mathrm{~nm})$.

High Speed Countercurrent Chromatography (HSCCC). Gradient Elutions The $n$-butanol fraction was fractionated on an HSCCC apparatus (P.C.Inc.) in four gradients (reverse phase) composed of (A) ethyl acetate- $n$ butanol-water $(140: 2: 80, \mathrm{v} / \mathrm{v} / \mathrm{v}),(\mathrm{B})$ ethyl acetate- $n$-butanol-water $(140$ $4: 80, \mathrm{v} / \mathrm{v} / \mathrm{v}),(\mathrm{C})$ ethyl acetate- $n$-butanol-water $(140: 6: 80, \mathrm{v} / \mathrm{v} / \mathrm{v})$ and (D) ethyl acetate- $n$-butanol-water $(140: 8: 80, \mathrm{v} / \mathrm{v} / \mathrm{v})$, using $(\mathrm{H} \rightarrow \mathrm{T})$, triple coil,

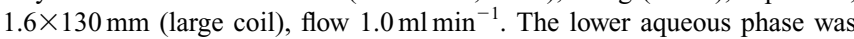
used as the stationary phase. The retention of the stationary phase for this solvent system was $87.7 \%$ at $850 \mathrm{rpm}$.

Analyses of the Compounds by TLC Aliquots of the $n$-butanol fraction were refractionated and the collected fractions ( 90 fractions) were analyzed on silica gel TLC with a mobile phase of chloroform-methanol-water $(43: 37: 20$, organic phase, $v / v / v)$. The spots on the TLC plates were observed under a UV lamp $(254,365 \mathrm{~nm})$, and then developed with NP/PEG Reagent. ${ }^{9)}$

Biological Material Capitulae of Eriocaulon ligulatum (VelL.) L. B. SмITH were collected in May of 1999, at Diamantina, Minas Gerais State Brazil and authenticated by Professor Dr. Paulo Takeo Sano from the Instituto de Biociências (IB) of Universidade de São Paulo (USP), (the Institute of Biosciences of the University of Sao Paulo) São Paulo. A voucher specimen (SANO ${ }^{\circ} 2978$ ) was deposited at the Herbarium of the IB-USP.

Extraction and Isolation Capitulae of E. ligulatum ( $300 \mathrm{~g}$ ) were separated, powdered and successively macerated at room temperature with $n$ hexane (21), methylene chloride (21) and methanol (21), being left for one week in each solvent. The solvents were evaporated under reduced pressure to yield gummy extracts. The yields for the hexane, the dichloromethane and the methanolic extracts from the dried powders of E. ligulatum capitulae were $0.93 \%, 1.45 \%$ and $3.55 \%$ respectively.

The methanolic extract $(4.0 \mathrm{~g})$ was partitioned three times with a mixture of ethyl acetate-water $(1: 1, \mathrm{v} / \mathrm{v})$. The ethyl acetate fraction was evaporated at $35^{\circ} \mathrm{C}$ under reduced pressure affording an ethyl acetate fraction of $1.25 \mathrm{~g}$. From the aqueous phase, $2.75 \mathrm{~g}$ was obtained.

The aqueous phase $(2.75 \mathrm{~g})$ was partitioned with a mixture of $n$-butanol-water $(1: 1, \mathrm{v} / \mathrm{v}$, repeated 3 times $)$, affording $1.15 \mathrm{~g}$ of extract in the resultant $n$-butanol phase and $1.30 \mathrm{~g}$ in the resultant aqueous phase. The $n$-butanol fraction $(450 \mathrm{mg})$ was subjected to HSCCC. Portions of $5 \mathrm{ml}$ were collected, monitored by TLC [silica gel plates eluted with $\mathrm{CHCl}_{3}-\mathrm{MeOH}-\mathrm{H}_{2} \mathrm{O}$
(43:37:20, organic phase, $\mathrm{v} / \mathrm{v} / \mathrm{v})]$ and developed with anisaldehyde $/ \mathrm{H}_{2} \mathrm{SO}_{4}$ solution and NP/PEG Reagent. ${ }^{9}$ From the HSCCC experiment, we were able to isolate flavonoids $(\mathbf{1}-\mathbf{3})$ which exhibited an increase in the mobile phase.

Fractions $40-49$ ( $7 \mathrm{mg}$ total) afforded 6-methoxyapigenin-7- $O-\beta$-D-glucopyranoside 1. Fractions $54-60$ (20 mg total) afforded methoxyapigenin7-O- $\beta$-D-allopyranoside 2 . Fractions $67-73$ (14 mg total) afforded $6,4^{\prime}-$ dimethoxyquercetin-3-O- $\beta$-D-6"[3,4,5-trihydroxy (E)-cinnamoyl]glucopyranoside 3. Compounds $\mathbf{1}$ and $\mathbf{2}$ were identified by their NMR spectra and by comparison with previous data reported in the literature. ${ }^{3)}$ Compound $\mathbf{3}$ was identified by its 1-D and 2-D NMR spectra IR, UV and HR-ESI-MS. The dichloromethane extracts $(2.0 \mathrm{~g})$ were fractioned using column chromatography on silica gel eluted with several gradient mixtures of hexane-ethyl acetate. Fractions $51-55(20 \mathrm{mg}$ total $)$ afforded the eriocauline 4 that was identified by 1-D and 2-D NMR spectra IV, UV and HR-ESI-MS.

6,4'-Dimethoxyquercetin-3-O- $\beta$-D-6" [3,4,5-trihydroxy $(E)$-Cinnamoyl]glucopyranoside (3): Yellow amorphous solid (mp 195.0-196.5 $\left.{ }^{\circ} \mathrm{C}\right) .[\alpha]_{\mathrm{D}}$ $-47^{\circ}\left(c=0.2, \mathrm{CH}_{3} \mathrm{OH}, 23^{\circ} \mathrm{C}\right) . \mathrm{CD}\left(0.1, \mathrm{CH}_{3} \mathrm{OH}\right):[\theta]_{217}+1250,[\theta]_{220}$ $-27500,[\theta]_{246}-33750,[\theta]_{264}+1200,[\theta]_{270}+13750$. UV $\lambda_{\max }(\mathrm{MeOH})$ $\mathrm{nm}(\log \varepsilon): 217$ (6.05), 240 (6.10), 276 (6.16), 336 (6.24). IR (KBr) cm ${ }^{-1}$. 3387, 1637. Positive HR-ESI-MS $m / z: 687.1561[\mathrm{M}+\mathrm{H}]^{+}, 693.1434$ $[\mathrm{M}+\mathrm{Na}]^{+}, 725.2463[\mathrm{M}+\mathrm{K}]^{+}, 301.1436\left[\mathrm{M}-\mathrm{C}_{16} \mathrm{H}_{20} \mathrm{O}_{11}+\mathrm{H}\right]^{+}, 507.1139$ $\left[\mathrm{M}-\mathrm{C}_{9} \mathrm{H}_{8} \mathrm{O}_{4}+\mathrm{H}\right]^{+}$. Anal. Calcd for $\mathrm{C}_{32} \mathrm{H}_{30} \mathrm{O}_{17}: \mathrm{C}, 55.98 ; \mathrm{H}, 4.40$, Found: $\mathrm{C}$, 55.98; $\mathrm{H}, 4.40$. For ${ }^{1} \mathrm{H}$ - and ${ }^{13} \mathrm{C}-\mathrm{NMR}$ analyses see Table 1 .

Eriocauline (4): Yellow amorphous solid $\left(\mathrm{mp} 152.5-153.7^{\circ} \mathrm{C}\right) .[\alpha]_{\mathrm{D}}$ $-16,5^{\circ}\left(c=0.2, \mathrm{CH}_{3} \mathrm{OH}, 23^{\circ} \mathrm{C}\right) . \mathrm{CD}\left(0.1, \mathrm{CH}_{3} \mathrm{OH}\right):[\theta]_{219}-8750,[\theta]_{253}$ $+3750,[\theta]_{265}-18750,[\theta]_{274}-15000,[\theta]_{281}-18700$. UV $\lambda_{\max }(\mathrm{MeOH})$ $\mathrm{nm}(\log \varepsilon): 240(6.10), 272.5(6.15), 401(6.32)$. IR $(\mathrm{KBr}) \mathrm{cm}^{-1}: 3416,1638$ Positive HR-ESI-MS $m / z: 527.1342[\mathrm{M}+\mathrm{H}]^{+}, 565.2244[\mathrm{M}+\mathrm{K}]^{+}, 294.0506$ $\left[\mathrm{C}_{15} \mathrm{H}_{11} \mathrm{O}_{5}+\mathrm{Na}\right]^{+}, 309.1509\left(\mathrm{M}-\mathrm{C}_{15} \mathrm{H}_{11} \mathrm{O}_{4}+\mathrm{K}\right)^{+}$. Anal. Calcd for $\mathrm{C}_{30} \mathrm{H}_{22} \mathrm{O}_{9}$ : C, 68.44; H, 4.21, Found: C, 68.43; H, 4.20. For ${ }^{1} \mathrm{H}$ - and ${ }^{13} \mathrm{C}-\mathrm{NMR}$ analyses see Table 2

Salmonella Mutagenicity Assay. Chemicals Dimethylsulfoxide (DMSO), nicotinamide adenine dinucleotide phosphate sodium salt (NADP), D-glucose-6-phospate disodium salt, L-histidine monohydrate, and D-biotin were purchased from Sigma Chemical Co. (St. Louis, MO, U.S.A.).

Standard Mutagens: Sodium azide $\left(\mathrm{AZ}, \mathrm{NaN}_{3}\right)$, 2-anthramine (2-AA), mitomycin $(\mathrm{MC})$, and 4-nitro- $O$-phenylenediamine (NPD) were also obtained from Sigma. Oxoid Nutrient Broth $\mathrm{N}^{\circ} 2$ (Oxoid, England) and Difco Bacto Agar (Difco, U.S.A.) were used for the preparation of bacterial growth media. All other reagents used to prepare buffers and media were from Merck (Whitehouse Station, NJ, U.S.A.) and Sigma.

Experimental Procedure The Salmonella mutagenicity assay was performed with S. typhimurium strains TA100, TA98, TA97a and TA102, preincubated for $20-30 \mathrm{~min}$ with the test substance, with and without metabolic activation. ${ }^{32)}$ The S9-mix was freshly prepared before each test using an Aroclor-1254-induced rat liver fraction purchased (lyophilized) from Moltox (Molecular Toxicology Inc.). S. typhimurium strains were kindly provided by Dr. B. Ames, University of California, (Berkeley, CA, U.S.A.).

The selected concentrations of the extracts and the experimental procedure were performed in accordance with our previous studies..$^{5,26,29,33)}$ The standard mutagens used as positive controls in experiments without S9-mix were 4-nitro- $O$-phenylenediamine $(10 \mu \mathrm{g} /$ plate $)$ for TA98 and TA97a, sodium azide $(1.25 \mu \mathrm{g} / \mathrm{plate})$ for TA100 and mitomycin $(0.5 \mu \mathrm{g} / \mathrm{plate})$ for TA102. In tests with metabolic activation, 2-anthramine $(0.125 \mu \mathrm{g} / \mathrm{plate})$ was used for all strains. DMSO (100 $\mu \mathrm{l} /$ plate) served as the negative (solvent) control.

The statistical analysis was performed with the Salanal computer program, adopting the Bernstein model. ${ }^{34)}$ The mutagenic index (MI), defined as the average number of revertants per plate divided by the average number of revertants per plate in the negative (solvent), was calculated for each dose. A sample was considered positive when the mutagenic index was equal to or greater than 2 for at least one of the tested doses and also if it had a reproducible dose-response curve. ${ }^{34}$

Acknowledgements We wish to thank the Fundação de Amparo à Pesquisa do Estado de São Paulo (FAPESP) for funding this project and the Conselho Nacional de Desenvolvimento Científico Tecnológico (CNPq) for financial aid to L.C.S., A.P.S.O. and W.V. and CAPES for funding provided to M.A.S.

\section{References}

1) Bate S. E. C., Harborne J. B., Phytochemistry, 8, 1035-1037 (1969)

2) Ho J. C., Chen C. M., Phytochemistry, 61, 405- 408 (2002).

3) Santos L. C., Rodrigues C. M., Silva M. A., Coelho R. G., Sannomiya 
M., Vilegas W., Biochem. Syst. Ecol., 33, 1159-1166 (2005).

4) Santos L. C., Piacente S., Cosimo P., Montoro P., Vilegas V., Rev. Braz. Farmacog., 13, 67-74 (2003).

5) Varanda E. A., Raddi M. S. G., Dias F. L. P., Araujo M. C. S., Gibran S. C. A., Takahashi C. S., Vilegas W., Teratog. Carc. Mut., 17, 85-95 (1997).

6) Tavares D. C., Varanda E. A., Andrade F. P. D., Vilegas W., Takahashi C. S., J. Ethnopharmacol., 68, 115-120 (1999).

7) Moraes T. M., Silva M. A., Rodrigues C. M., Santos L. C., Sannomiya M., Rocha L. R. M., Brito A. R. M. S., Vilegas W., Hiruma-Lima C. A., Phyt. Res., 2007 (submitted).

8) Batista L. M., Almeida A. B., Pietro L. M., Toma W., Calvo T. R., Vilegas W., Souza-Brito A. R., Biol. Pharm. Bull., 27, 328-332 (2004).

9) Wagner H., Bladt S., Zgainski E. M., "Plant Drug Analysis,” Springer, Berlin, 1984

10) Agrawal P. K., "Carbon 13 NMR of Flavonoids," 1st ed., Vol. XXXIX, Elsevier, Amsterdam, 1989

11) Vilegas W., Santos L. C., Alecio A. C., Pizza C., Piacente S., Pauw E., Sano P. T., Phytochemistry, 49, 207-210 (1998).

12) Santos L. C., Piacente S., Pizza C., Albert K., Dachtler M., Vilegas W. J. Nat. Prod., 64, 122-124 (2001)

13) Coelho R. G., Vilegas W., Devienne F., Raddi M. S. G., Fitoterapia, 71, 497-500 (2000)

14) Vilegas W., Dokkedal A. L., Rastrelli L., Piacente S., Pizza C., J. Nat. Prod., 62, 746-749 (1999).

15) Vilegas W., Nehme C. J., Dokkedal A. L., Piacente S., Rastrelli L., Phytochemistry, 51, 403-409 (1999).

16) Dokkedal A. L., Salatino A., Biochem. Syst. Ecol., 20, $31-32$ (1992).

17) Santos L. C., Piacente S., De Ricardis F., Eletto A. M., Pizza C., Vilegas W., Phytochemistry, 56, 853-856 (2001).

18) Ricci C. V., Patricio M. C., Salatino M. L., Salatino A., Giulietti A. M., Biochem. Syst. Ecol., 24, 577-583 (1996).

19) Coelho R. G., Vilegas W., Parra L. R., "Flavonoids C-Glicosilados de
S. bisulcatus," 22nd Annual Meeting of Brazilian Chemical Society, Abstracts, 17-18, 1999 .

20) Coelho R. G., Vilegas W., Parra L. R., Sano P. T., "Estudo Químico dos Escapos de S. bisulcatus," III Meeting of the Phytochemistry Latin-American Society of Phytochemistry, Abstracts, 71, 1999.

21) Giulietti A. M., Bol. Bot. Univ. São Paulo, 6, 39- 47 (1978).

22) Harborne J. B., Recent Adv. Phytochem., 4, 107-141 (1972)

23) Giulietti A. M., Scatena V. L., Sano P. T., Parra L. R., Queiroz L. P. Harley R. M., Menezes N. L., Yseppon A. M. B., Salatino A., Salatino M. L., Vilegas W., Santos L. C., Ricci C. V., Bonfim M. C. P., Miranda E. B., "Multidisciplinary Studies on Neotropical Eriocaulaceae. Monocots: Systematics and Evolutions," CSIRO Publishing, Australia, 2000, pp. $580-588$.

24) Zeiger E., Regul. Toxicol. Pharmacol., 28, 85-95 (1998).

25) Mortelmans K., Zeiger E., Mutation Res., 455, 29-60 (2000).

26) Varanda E. A., Devienne K. F., Raddi M. S. G., Furuya E. M., Vilegas W., Toxicology in Vitro, 18, 109-114 (2004).

27) Park S., Hahm K. B., Oh T. Y., Jin J. H., Choue R., Dig. Dis. Sci., 49 384-394 (2004)

28) Toker G., Küpeli E., Memisoglu M., Yesilada E., J. Ethnopharmacol., 95, 393-397 (2004).

29) Cardoso C. R. P., Cólus I. M. S., Bernardi C. C., Sannomiya M., Vilegas W., Varanda E. A., Toxicology, 225, 55-63 (2006).

30) Jurado J., Alejandre D. E., Alonso M. A., Pueyo C., Mutagenesis, 6, $289-295$ (1991)

31) Schimmer O., Hafele F. F., Kruger A., Mutation Res., 206, 201-208 (1988).

32) Maron D. M., Ames B. N., Mutation Res., 113, 173-215 (1983).

33) Varella S. D., Pozetti G. L., Vilegas W., Varanda E. A., Food Chem. Toxicol., 42, 2029-2035 (2004).

34) Bernstein L., Kaldor J., McCann J., Pike M. C., Mutation Res., 97 267-281 (1982) 